NBER WORKING PAPERS SERIES

EXPECTED CHANGES IN THE WORKFORCE

AND IMPLICATIONS FOR LABOR MARKETS

Phillip B. Levine

Olivia S. Mitchell

Working Paper No. 3743

\author{
NATIONAL BUREAU OF ECONOMIC RESEARCH \\ 1050 Massachusetts Avenue \\ Cambridge, MA 02138 \\ June 1991
}

The order of the authors' names has been determined alphabetically. Views contained herein are solely those of the authors, and not those of the institutions with whom the authors are affiliated. Without implicating them, we thank Brenda Lapp for excellent research help, John Stinson who provided unpublished tabulations of labor force data, and Joseph Quinn for useful comments. This paper is part of NBER's research program in Labor studies. Any opinions expressed are those of the authors and not those of the National Bureau of Economic Research. 
NBER Working Paper \#3743

June 1991

\begin{abstract}
EXPECTED CHANGES IN THE WORKFORCE
AND IMPLICATIONS FOR LABOR MARKETS
\end{abstract}

\begin{abstract}
This paper examines the likely effects of the aging of the baby boom on labor force attachment, unemployment, and wages. Labor market trends between now and 2020 are the focus of analysis, when the majority of the baby boom generation will confront its retirement decision.
\end{abstract}

We begin by reviewing past labor force trends and discussing important limitations of existing projection methods. Key elements needed to project the consequences of the demographic shock facing the labor market are identified. The task of developing a fully specified economic model to examine the effect of the aging of the baby boom on the labor market is as yet incomplete. On the basis of the best available evidence, we suggest the following conclusions can be drawn:

- The trend towards earlier retirement will slow and perhaps reverse in the next few decades.

- Unemployment should fall among older workers and the aggregate full-employment unemployment rate should also decline as the baby boom ages.

- The aging of the baby boom will not depress wages substantially, either for older workers or for other demographic groups.

Phillip B. Levine

Department of Economics

Princeton University

Princeton, NJ 08544
Olivia S. Mitchell

Department of Labor Economics

266 Ives Hall - ILR

Cornell University

Ithaca, NY 14853-3901

and NBER 


\title{
Expected Changes in the Workforce and Implications for Labor Markets
}

\author{
Phillip B. Levine and Olivia S. Mitchell
}

\section{Introduction}

While many have written about possible effects of the baby boom on the U.S. economy, few have recognized that this demographic transition provides analysts with a unique and valuable opportunity to investigate how the labor market works. Specifically, as baby boomers move up the age distribution, they impart a one-time shock to the supply of potential workers in each age bracket. Because this change is exogenous, many of the tools labor economists typically apply can be utilized to predict how the aging of the baby boom will alter key labor market outcomes. Theorecical and empirical models which (either implicitly or explicitly) hold constant structural parameters in order to work through the effects of an exogenous shock are well-suited to address this issue.

The goal of this paper is to use economic tools to analyze the impact of the baby boom on three key labor market outcomes: labor force participation rates, unemployment, and wages. We concentrate mainly on this particular cohor's labor market outcomes, but also consider the implications of this group for the labor market as a whole. Since most of the prime-age population participates in the labor market, we focus analysis on labor market trends between the period between the present and 2020 , when the majority of the baby boom generation will confront the retirement decision. Consequently, an important topic of discussion will be retirement patterns of older workers and a consideration of whether the trend towards earlier retirement will continue in the next three decades. In addition, we briefly examine the effects of the aging baby boom on unemployment, and on wages for older workers as well as for workers of other ages.

Our review of the evidence leads us to conclude that trends towards earlier retirement will slow and perhaps reverse. New Social Security rules have already been enacted to encourage later 
retirement. Pension incentives towards early retirement will be curtailed as fewer workers will be available to replace retiring baby boomers. A great deal of evidence indicates that financial incentives have a strong impact on workers' retirement decisions, so these changes in pensions and Social Security should slow the trend toward earlier retirement. Our prediction is further supported by data on projected changes in workforce composition. Since growth will probably not be concentrated in the blue-collar sector where worker's productivity is more likely to decline with age, early retirement may be avoided by more workers in the future.

We also conclude that the aging labor market will bring with it a reduction in unemployment, and will have little impact on relative wages. Both unemployment among older workers and the aggregate full-employment unemployment rate should fall as the baby boom ages. While job displacement of older workers currently leads to substantial hardship, this problem should be somewhat reduced in the future. In future economic expansions, businesses will not be able to rely on a young "reserve army of the unemployed" to fill new positions as in the past; displaced older workers may more often become the new recruits. Steady state aggregate unemployment should also fall as the labor force becomes more heavily weighted with older workers with traditionally lower unemployment rates. The effect of baby boom aging on wages is more difficult to track because employers have the potential to substitute capital for labor, and to hire workers from other demographic groups. However, controlling for all such interactions, there is no support for the conclusion that wages will be substantially depressed either for older workers, or for other demographic groups.

The argument is developed in three parts. A first section reviews recent labor force trends and discusses published predictions regarding retirement patterns as the baby boom ages over the next three decades. The second section identifies determinants of retirement suggested by the labor economics literature of the past decade and offers informed judgement about possible future participation patterns. The third part of the paper briefly examines the effects of an aging baby boom on unemployment and wages. A brief summary concludes the discussion. 


\section{Labor Force Trends. Past and Future}

Before examining projections regarding the future labor force, it is useful to briefly review labor force developments to date as well as the explanations for these patterns. Here we sketch past trends in labor force participation, and then go on to discuss previous effors to project labor force figures into the future.

\section{Looking Backward: Labor Market Trends to 1990}

Labor force participation trends for older workers and over have been the subject of intense discussion and debate in recent years. There is general agreement over several key facts:

- Labor force participation rates for older men have dropped by half since 1900.

Among men age 60 and older, 66 percent were in the labor force in 1900, according to archival evidence, while less than half that many, 26 percent, were active by 1990 (Table 1).

-The trend to earlier retirement among men has not been a steady ore. In fact, men's participation rates were quite stable between 1900 and the mid-'30's, then began falling in 1937, continued falling steadily for fifty years through the late 1980's. (Figure 1). It is possible that the trend to early retirement may actually have reversed over the last two years, inasmuch as participation rates have risen in the 60-64 age range for two years in a row -- a phenomenon almost without precedent in the last quaner century in the United States. (Detailed age breakdowns by age appear in Figure 2 for men age 60-61 and 62-64 since 1960 ).

- Labor force trends for women have been more mixed over the century. Since 1900, older women's labor force attachment figures rose, but their rates over the century fell relative to younger women. Around 1900, older women's (age 55-64) participation rates stood at 21 percent for nonmarried women, and 2 percent for wives. By 1980, participation rates for older nonmarried women rose to 54 percent, and 37 percent for older wives. (Goldin 1990). Older 
women's participation rates are still about twenty percentage points below those of younger women (USDOL 1991).

-For older women the trend to earlier retirement may have reversed slightly in the last five years. As Figure 2 indicates, labor force participation rates of women in their early 60 's have risen slightly since about 1986. Nevertheless, older women's participation rates remained at only two thirds those of similar aged male rates by 1990 .

Overall, the evidence demonstrates a clear and increasing tendency not to work at older ages among men, and a relative decline in participation among older women over time.

Labor market status of older people has also been examined using other variables as well. Some analysts examine whether or not an individual was employed during a short period of time (e.g. work during a single survey week) while others tabulate peoples' affurmative answers to questions like "are you now retired?" as an indication of retirement status (Fields and Mitchell [1984] and Quinn et al [1990] review various definitions of retirement status). Most of these data are not available over time, so cannot reveal much about trends in labor force attachment.

There is somewhat more research on what has been called "partial" or "phased" retirement, generally viewed as employment subsequent to one's career job with either fewer hours of work per week, or at a lower wage rate, or both. An investigation by Gustman and Steinmeier (1984) showed that almost a quarter of the 64-year old and 38 percent of the 69-year old men examined considered themselves partially retired by this measure during the 1970's. Subsequent analysis of the same data set by Quinn et al. (1990) confirms that most of these individuals spend only a short time in this partial retirement status, moving out of the labor force thereafter rather rapidly. Whether partial or phased retirement is gaining ground among the older workforce of the 1990's cannot be determined yet, since there is no current longitudinal survey of this group. It is anticipated that data necessary to examine these trends in the near future will be provided by the 
new Health and Retirement Survey, under development by the University of Michigan's Institute for Survey Research and funded by the National Institute on Aging.

Last but not least, there is ample evidence that part time work has become more important in older people's work patterns. As Quinn et al (1990) demonstrate, there is a large jump in the prevalence of part time work at age 65 , from 6 to 48 percent for men, and from 20 to almost 60 percent for women. This patnem complements other indicators of the trend toward early retirement in the U.S. labor market: fewer people are remaining employed at older ages, and when they do they are increasingly likely to work part-time rather than full time.

\section{Looking Forward: Published Labor Force Ptojections for the 21 Century}

Will this powerful trend to earlier retirement in the US labor market continue? Over the past few decades, labor force projections by the U.S. government, combining predicted population trends and LFPR's, have become quite common. This section will consider where these projections come from and what can be leamed from them.

There are at least three major sources of labor force projections produced by research and policy organizations and widely discussed in public policy circles. The Bureau of Labor Statistics (BLS) regularly presents projections with a relatively short horizon, typically no longer than 15 years into the future. Two other govermment agencies have provided labor force projections further into the future. The Bureau of Economic Analysis (BEA) publishes a report every five years with projections that extend 50 years. In addition, the Social Security Administration (SSA) has projected the size of the labor force to the year 2060 . This agency's report was not part of a continuing research program, however. It was conducted in the early 1980's to determine whether existing financing methods could generate enough revenue to provide benefits to the anticipated larger cohons of retired workers.

As noted above, the projected size of the labor force is the product of two elements, the anticipated size of the population and labor force participation rates. Since Preston's paper at this 
conference extensively analyzes population projections, we focus here on predicted labor force participation rates.

The methodology that is employed in each these projections is quite similar (c.f. Flaim and Fullerton 1978 for a detailed description of the BLS projection method). Typically, past trends are extrapolated to predict future behavior. Ad hoc manipulations are then made to eliminate impossible results (e.g. labor force participation rates greater than 100 percent or less than 0 percent) or results which are "highly implausible" (e.g. women's labor force paricipation rates higher than men's). Minor adjustments are also made for other factors, such as the level of economic growth (all projections presented here assume moderate growth). Some of the projections are intertelated as well; the BEA's longer term projections star with the predicted rates of the BLS and then extrapolate this series.

Table 2 presents alternative projections of the civilian labor force participation rate for selected years and different demographic groups, in addition to a snapshot of current participation rate patterns. The evident similarity in predicted participation rates for a given demographic group (especially for men) is indicative of the similarity in techniques employed. For instance, the participation rate predicted by the BEA for all men in 2015 is identical to the one predicted by SSA for 2020: both agencies indicate that market attachment among men will fall from the current level of 76.1 percent to 72 percent over the next 25 to 30 years. This prediction is largely a result of the population being more heavily weighted towards older workers who have lower labor market attachment.

There are some differences in projected rates for individual age groups among men, however. Both the BLS and BEA project a continuing small decline in LFPR's among older men (over age 65), while the SSA does not. On the other hand, the SSA's projected growth in teenage labor force participation is considerably greater than in the BEA and BLS.

Projections for women are more variable, as one might expect given dramatic changes in fermale labor force participation of the recent past. As was the case for the men, market attachment among women as a whole is predicted to decrease after the year 2000 because of the changing age 
composition of the workforce. Estimates of labor force behavior among individual age groups show marked discrepancies across projections, however. The BLS and BEA project a continued large increase in participation among prime-age women while the SSA predicts virtually no change. Also, SSA projections for older women show virtually no change from current rates, while the BLS and BEA show a slight trend towands earlier retirement.

Historically, labor market projections seidom resemble observed behavior. As we will demonstrate, relatively short-term projections by the BLS have not been very reliable for many demographic groups where labor supply patterns have undergone change in the last decades. This calls into even greater question the BEA and SSA projections extending beyond the next 15 years, well into the 21 st century.

Tabie 3 collects three BLS projections for age/sex groups made at three different points in time, along with the observed participation rates in that year for that group. One striking observation is that in some instances, the difference between projected and observed rates is over 50 percent. Groups where projections are fraught with the largest errors, as one might expect, are women and older workers. For example, the 1985 rate for women aged $25-34$ projected as of 1970 was 46.7 percent, but the observed 1985 rate was 70.9 percent. The projections are not always underestimates; thus, for instance, 35.9 percent of men aged 65-69 were projected to participate in the labor force in 1985 , but only 24.4 percent actually did.

Another observation about these projections is that the pattern of discrepancy has changed over time. Comparing actual data with projections for 1980 and 1985 , two patterns were clear: more women were entering the labor market and more men were retiring at younger ages than anticipated. However, in 1990 these pattems appear to have reversed to some extent. Projected participation for younger women, between the ages of 16 and 24 , was actually higher than observed. Similarly, more older workers (over age 55, both men and women) remained in the labor market than projections indicated.

This finding highlights an inherent flaw in projection technology which essentially relies on a linear extrapolation with only minor modifications. When behavioral patterns change, 
projections using the existing methodology will be "too slow" to respond. To illustrate this problem, consider observed and projected participation rates for women aged $20-24$, one of the demographic groups undergoing volatile change in their labor market behavior during the last twenty years. (Note that while the focus of this section is clearly on labor force behavior of older workers, this younger group was chosen for analysis here because it presents the best example of the pattems we seek to explain). Figure 3 presents observed participation rates for this group from 1946 through 1990 , along with four projections we have made through a simple linear extrapolation technique. To correspond as closely as possible to Table 3, we project future labor force participation rates for 1980, 1985, and 1990 using data available in 1965, 1970, and 1978, respectively. In addition, participation in the year 2000 is also projected. The 20 years of observed participation rates immediately preceding the projection date are used to estimate the linear trend. Observed participation rates in the projection year are then incremented by the trend to predict funre values.

As reported in Table 4, rates predicted for 1980, 1985 and 1990 using linear extrapolation are remarkably similar to those projected by the BLS for this demographic group. This suggests that the BLS's judgmental adjustments to extrapolated rates were relatively minimal. Nevertheless, there is a huge difference between the observed and projected rates. Projected figures understate the observed in 1980 and 1985, and overstate them in 1990 . This example provides a clear indication of the problems inherent in existing projection methodology. When the rate of change in LFPR's is increasing, linear extrapolation leads to underpredicted values without adjusting extrapolated rates. Similarly, decreasing rates of change lead to overpredicted participation rates. Both of these effects are observed in Figure 3. The fact that extrapolated rates to the year 2000 are significantly different than the BLS projections (as shown in Table 4) indicates that in more recent projections, larger adjustments must have been made.

Figures 4 and 5 and the remainder of Table 4 report the results of similar analyses for older male and female workers (age 55-64). For older men, the increasing rate of early withdrawal from the labor force led to overpredictions of the participation rate until the trend towards early 
retirement slowed in the mid 1980's. This last effect produced an underestimate of men's participation for 1990. Note that the similarity in the linear extrapolations and the BLS projections indicates that through 1990, few ad hoc adjustments were made to reported rates. However, the fact that the BLS projections for the year 2000 are considerably higher than those obtained from linear extrapolation indicates that a large ad hoc adjustment must have been made.

For older women, the increasing participation rates prior to 1965 led to substantially overprojected rates for 1980 and 1985. In contrast, the relatively constant rates from 1965-85 led to projected rates being too low in 1990, after rates began to rise again. The BLS projections for this demographic group, however, have been consistently lower than those obtained by linear extrapolation, indicating ad hoc reductions in projected rates occurred regularly through 1990 . For the year 2000 , the BLS has now adjusted projections, raising the rate obtained by linear extrapolation.

This section has extensively investigated the limitations of projection methods currently used for "short-term" labor force projections. The problems in this exercise should cast serious doubt on even longer term projections carried out by a variety of agencies and analysts. Our goal has not been to indict current methodology, since under many circumstances it may be the best technique available. Changes in the underlying structural parameters of the labor market are difficult to predict in many cases, implying that a mainly statistical procedure which masks the effects of these economic factors may be the simplest approach. On the other hand, we believe there are economic factors which should also inform a model used to project future labor force outcomes. It is to the development of this model we tum next.

\section{Economic Models of Retirement Trends}

To understand how the baby boom will affect labor markets, an economic model of behavior should be constructed. As argued at the outset, models of this son would be particularly useful in this context because they hold constant structural parameters in order to work through the effects of an exogenous shock such as the one imparted on the labor market by the baby boom. 
Nevertheless, the task of developing a fully specified economic model to examine the effect of the aging of the baby boom on the labor market is at present not possible. Indeed it probably will require many more years of research. Instead of presenting a clearly inadequate formal model, we instead undertake the job here of describing the building blocks that a fully specified model will cerainly need to incorporate. This section employs these building blocks to the question of how retirement trends might be expected to change as we move toward 2020.

\section{The Economic Determinants of Early Retirement}

Ten years ago, many researchers in the retirement field believed that most older workers remained employed as long as possible, and retired only when forced to by poor health, mandatory retirement, or other "push" factors. However, this view has been deeply undermined by the last decade of retirement research.

\section{The Role of Poor Health:}

It is cerrainly the case that health problems force some older workers to leave their jobs. When this occurs, it must be agreed that retirement is not a choice but rather a necessity compelled by poor health. The important issue, however, is how numerous are such people and whether the incidence of disabling health problems is increasing among the population experiencing earlier retirement -- that is, workers in their late 50's and early 60 's.

After reviewing the evidence, we believe that (1) there is little support for the view that health is a major factor explaining early retirement, and (2) increasingly poor health cannot explain the long-term trend toward earlier retirement in the United States. We focus first on the importance of health as a determinant of early retirement. Here the evidence shows that relatively few give health-related reasons for retirement. For example, only 12 percent of more than one thousand men surveyed by the Social Security Administration gave poor health as the primary reason for leaving their main job (Fields and Mitchell 1984). In addition, many researchers note that these statistics will overstate the role of poor health because retirees' own assessment of their health 
status is colored by illness/disability being a socially acceptable rationale for retirement, and because reporting oneself to be in poor health is a prerequisite for various government transfer payments. An excellent review of recent studies can be found in Sammartino (1987). When researchers examine more "objective" health measures from clinical sources, evidence on impaiments, and mortality outcomes, they generally conclude that health has some role to play, but by no means is it as important as economic variables in explaining labor market withdrawal (Fields and Mitchell 1984, Quinn et al. 1990). Thus most workers retire for reasons other than poor health.

The weight of the evidence is also not supportive of the claim that the long-term trends toward early retirement was driven primarily by worsening health among workers in their late 50 's and early 60 's. The evidence is somewhat mixed, because problems arising in self-reported health measures become exacerbated over time. Thus, for instance, Bailey (1987) notes large increases over time in the number of self-reported days of limited activity due to illness or disability among those age $45-64$, as well as among the elderly. However the survey questionnaire was changed in the late 1960's, resulting in the same number of people reporting health limitations, but a large increase in the extent to which health limitations were deemed restrictive. Thus the time trend Bailey repors in health limits is less than fully persuasive. Similarly, disability cases seem to be increasing in the older population over time, but changes in eligibility rules for Social Security Disability benefits may explain a large part of this trend. On the one hand, it seems clear that a much older population will have more health problems than will a younger group (Poterba and Summers 1987). On the other hand, there is no strong evidence that the health status of those age 55 to 65 deteriorated sufficiently to explain the strong decline in work among this age group from World War II onward.

\section{Mandatory Retirement:}

Prior to 1978 , many employers imposed mandatory retirement at age 65 . This policy was altered in 1978 with the Federal Age Discrimination in Employment Act, which moved the 
mandatory retirement age to 70 ; subsequen ly the age bar was lifted altogether for most private sector employees.

Even before mandatory retirement was outlawed, however, most firms did not force older workers out using this policy (Fields and Mitchell 1984). Less than half of all private sector workers during the early 1970's were in jobs covered by mandatory retirement provisions, and fewer than 5 percent of retirees appear to have worked long enough to have been forced out by mandatory retirement. Thus it seems safe to conclude that mandatory retirement was not an increasingly powerful force driving workers to early retirement over the last several decades.

Having established that most older workers are not forced to retire, it is necessary to then elaborate other explanations for early retirement. Research on workers reaching retirement age has demonstrated that preeminent among these other explanations are economic factors, including most importantly wages and retirement wealth. Along these lines, an analysis of older men's retirement pattems by Fields and Mitchell (1984) concluded that economic factors such as wages and retirement benefits accounted for three-quarters of the explained variance in retirement ages across people, while poor health was found to account for only one-quarter.

\section{Wealth:}

One factor which certainly played a role in inducing earlier retirement over time was an increase in overall wealth. U.S. economic growth since World War II contributed importantly to real wage growth over time, despite periods of inflation and economic slowdown. During most of their productive lifetimes, workers earned more and accumulated more assets than their parents' cohorts. As a consequence, succeeding generations of older persons attained retirement age in better economic conditions than at most any time in the past (Burkhauser and Quinn 1989). Since leisure is a normal good, in economic terms, this increase in older people's wealth permitted additional consumption of retirement years over the decades (Fields and Mitchell 1984). 
Long-term asset growth was accompanied by two other developments which also permitted, if not encouraged, earlier retirement: the growth of the U.S. Social Security system, and the maturation of the private pension system.

\section{Social Security:}

Several different institutional features of the Social Security system contributed to make early retirement incteasingly attractive and feasible over time in the US. First, coverage grew rapidly over the post-WWII period: only about 60 percent of the labor force was covered during the 1950's, whereas over 90 percent of all workers are covered now (Aaron, 1982). Almost all retirees today receive some income from Social Security, compared to only about one-third of all private sector workers receiving a pension (Piascentini and Cerino 1990).

A second institutional change implemented in Social Security over time had to do with the age at which a worker could first become eligible for Social Security retirement benefits. This age, initially set at 65, was dropped for women to age 62 in 1956, and for men in 1961 (Rejda 1982). The fact that retirement payments are payable at 62 has enabled many to afford early retirement that they might not have been able to afford otherwise.

Another way in which Social Security changed making retirement more atractive over time had to do with benefit growth. After taking into account inflation, the average Social Security benefit payable to a newly retired male rose 50 percent in real terms between 1955 and 1985 (Ippolito, 1990). Pre- and post-retirement increases of massive proportions were legislated by a Congress eager to more than protect benefits against inflation, a policy which made retrement more affordable, and thus increasingly prevalent, among older Americans over time.

Two additional features of Social Security have been cited as contributing to earlier retirement. One is that at various points over the years, benefits under the system were structured to subsidize early retirement (Fields and Mitchell 1984). This occurred when the present value of future Social Security benefits payable to a worker who retired early (age 62) were just as high as (or higher than) the present value of benefits payable to someone deferring early retirement. This 
situation grose somewhat inadvertently, because the rules specified that someone who worked to age 65 paid more tax than if he retired early, yet age- 65 benefits were not enough larger to offset this additional tax payment. In addition, the early retiree would enjoy leisure, further weighting the balance in favor of leaving early.

A different way in which Social Security discouraged continued work after eligibility for benefits is via the so called "earnings test". This regulation permits the older benefit recipient to work and earn up to a threshold level, after which point Social Security payments begin to be reduced to offset additional earnings. This Social Security "eamings test" is certainly a labor market deterrent to some older workers, but several studies have also demonstrated that it is not relevant to many others (Leonesio 1990). Part of the reason that the eamings test may not deter work at older ages is that for some people, additional eamings beyond age 60 can have a pronounced positive effect on the Social Security Primary Insurance Amount (this is particularly imporant when high nominal earnings after age 60 replace low or zero wages earlier in life). While there is still some controversy about the political wisdom of retaining the eamings test, the evidence suggests that removing it would not induce much more work among the older population though it would cost the system a great deal (Gustman and Steinmeier 1991).

While Social Security benefits certainly grew more generous for those retiring since World War $\Pi$, these benefit increases must be weighed against increases in taxes which accompanied the growth of the system. Taking into account this factor also suggests a damping effect: beneficiaries retiring in 1950 eamed an implicit (risk-free) return on their contributions of about 20 percent per year in real terms, far exceeding that which they could have earned in the private market. The rate of return on contributions was about 12 percent for workers retiring only 15 years later (Moffitt 1977), and will probably be even smaller, if not negative, in the future. What this implies is that cohorts retiring forly years ago received relatively greater wealth transfers from the system than do today's older workers, providing those early groups with stronger early retirement incentives than were afforded to later ones. Hence the so-called "start-up" phase of Social Security provided the first several retiring cohors more wealth than later cohorts got, suggesting a diminution of 
retirement incentives in recent years. Whether and how retirement trends will respond to future Social Security changes is taken up again in a subsequent section.

\section{Pensions:}

A variety of labor market institutions have made early retirement more attractive in the last several decades, particularly the growth and development of employer-sponsored pensions. The growth of the private pension system has been striking: immediately following World War II, only 19 percent of private sector wage and salary workers were covered by pension plans, whereas by 1987 the fraction covered was 46 percent (Turner and Beller 1990) This rapid growth in pension coverage has moderated and perhaps even tumed around over the last five to seven years, however, evidently because of changing labor force composition, a shift to smaller firms and a trend away from unionized manufacturing jobs (e.g. Clark and McDermed 1990).

There is ample evidence that employers and their workers enable and often encourage earlier retirement over time, often by means of their pension plan. Recent research has shown that defined benefit plans frequently offer attractive incentives to retire before age 65 , and many do not impose an actuarial reduction in benefits among those leaving early (Mitchell, forthcoming [a]). Retirement supplements and bonuses, early retirement window plans, and a variety of other mechanisms have the effect of offering benefits which are largest if the worker retires as soon as he or she is eligible (Mutchler 1986, Lumsdaine et al 1990). In other words, the present value of the worker's recirement annuity stream from a defined benefit plan will often be maximized if early retirement is accepted, but will gall the longer retirement is delayed (Mitchell and Fields, 1985). Not only do such pensions offer retirement wealth which enables workers to retire earlier, but also they structure benefits in such a way that workers can leave early without suffering large benefit cuts. These pattems have a potent effect on workers' retirement decisions, a finding supported by dozens of econometric studies conducted during the 1980's and carefully reviewed by Quinn et al (1990). 
The effect of defined benefit pensions on retirement is indisputable, but in order to account for trends in early retirement it must also be demonstrated that corporate pension policy changed over time in such a way as to increase the appeal of leaving early. Evidence on this point, while difficult to obtain, is beginning to emerge in studies of specific companies tracked over time (Luzadis and Mitchell forthcoming; Ippolito 1990). Available evidence offers evidence that at least some defined benefit plans changed their retirement incentives between 1960 and 1980 in such a way as to increase the financial attractiveness of early retirement. This was accomplished by increasing benefit payments and tilting pension benefit formulas to lower the age at which pension benefit streams were maximized. Though explanations for these patterns are still only suggestive, it is likely that these early retirement incentives grew more pronounced over time in less profitable furms, and for workers with longer time on the job. It must be concluded that if pension plans could be structured to make early retirement more appealing, it will be possible to reverse this trend should labor shortages develop requiring extending the worklife.

\section{Wages:}

Wage pattems by eduction have diverged substantially over the last two decades, and this subject has been the subject of intense study. In the main, this literature tends to conclude that wages are becoming increasingly unequal over time, with earnings becoming particularly stagnant among the least educated segment of the workforce (cf. Levy 1987). However few analysts have narrowed the analysis to the older segment of the workforce and there is little evidence on whether these wage trends are exacerbated among the older age group. Hence it is not currently known whether falling wages may have contributed to earlier retirement trends experienced in the past decade. 


\section{Modeling the Effects of Euture Demographic Change on Early Rerirement}

Having identified above the most imporant regulatory and economic factors affecting retirement outcomes, it remains to discuss how these factors might be anticipated to affect retirement patterns as the labor force ages.

Focusing furst on the regulatory environment, we suspect that changing incentives will lead to a reduction or reversal in the trend towards early retirement. Many government policies have recently been implemented to encourage continued work both now and in the future. This includes legislation raising and then eliminating the practice of mandatory retirement for most sectors of the labor market, as well as age discrimination legislation and disability regulations providing opportunities for older workers to remain employed in the future should they so wish.

Social Security rules were also altered with reforms legislated in 1983, policies which will be affecting retirement incentives for cohorts of retirees well into the 21st century. In summary form, it is fair to characterize these reforms as raising the normal retirement age under Social Security from age 65 to 67 for baby boomers, and reducing benefits for those retiring prior to age 65. Additionally these reforms subjected a portion of retirees' Social Security benefits to income tax, which in turn reduces the net payoff to retirement and increases the relative attractiveness of remaining employed. Unfortunately, the specific Social Security reforms undertaken will probably have only a tiny effect on retirement patterns over the next thirty five years, according to numerous evaluation studies using a variety of economic models. Instead, what will probably occur at least in the near term is that workers will continue to retire at roughly the same age, but will be more at risk for old-age poverty because benefits are lower (Mitchell, forthcoming [b]).

Other pressures on federal budgets may also affect retirement pattems. For example the nation's health insurance program for people age 65 and over, Medicare, is scheduled to run out of money several years before the baby boom reaches retirement age (Aaron et al 1989). These pressures will cerainly strengthen the govemment's intentions to reverse the early retirement trend, though gradual changes in entidement programs may not be effective in achieving this end. 
The other factor affecting retirement trends, as argued above, is employer-provided pensions. Here too several changes may be anticipated (Andrews and Mitchell 1986). Pensions may become less widespread and/or less generous in the furure if, for example, marginal tax rates fall thereby reducing the appeal of pensions as a savings device. If Congress limits or ends the tax-preferred status of pensions in the future, this would seriously decrease pension plans' appeal as a retirement savings devise and diminish the prevalence of corporate pensions. It also is possible that the baby boom generation may receive lower total compensation because of its sheer size (more on this below), implying that pensions may become less prevalent. Other factors also likely to reduce pension coverage are declining firm size and changing industrial mix. Economies of scale make retirement investment more efficient in larger firms, but as the service sector replaces the shrinking manufacturing sector, where smaller firms are more prevalent, demand for pensions will decline relative to the past. Related to this is the fact that union workers have traditionally negotiated pensions more often than their nonunion counterparts; however most labor experts predict continued stasis in the union sector, suggesting that on this count as well pensions will decline in imporance in the future.

Government pension policy will also play a role in shaping the environment within which firms structure their pension plans. A host of recent reforms have raised pension costs and reduced the flexibility of compensation arrangements, including provisions limiting integration of pension benefits with Social Security payments, ceilings on the amount of contributions that can be accumulated on a tax-deferred basis, and prohibitions against using age in pension computations. Firms are now required to continue accruing pension benefits after the normal retirement age for older workers, ruling out cuts in benefit accrual and thus inducing early retirement (Mitchell, forthcoming [a]). Additionally, a very recent reform outlaws the use of age as a criterion in earlyout window plans, further limiting furms' ability to reward early retirement. These developments place constraints on the range of policies firms can adopt in the future regarding retirement age policy. If government policy continues to restrict pension practices, this makes providing pensions increasingly costly. Some of these additional costs may be offset by reducing wages or other 
employee benefits, but in other cases firms may be forced to terminate their pension plans which in rurn will reduce the incentives to retire early (Mitchell, 1990).

Some nonfinancial factors are also likely to affect retirement pattems. For example, changes in productivity among older workers may also affect the decision to leave the labor force. Mitchell, Levine, and Pozzebon (1988) review evidence indicating that differences in retirement behavior across industries and occupations are correlated with differences in age/productivity profiles. Specifically, workers in blue collar occupations have been shown to retire relatively earlier and to face greater productivity declines with age. However, at a macroeconomic level, the movement away from manufacturing towards the service sector will lead to a smaller share of blue collar jobs in the economy. Hence, diminished productivity should be less of a problem for older workers and they may be expected to remain in the workforce longer as we move into the $21 \mathrm{st}$ century.

The changing health status of older workers may have an impact on future retirement behavior though there is controversy about the direction this will take. Most workers do not retire for health-related reasons, and it may be that the small percentage that does should decline as a result of improving health status in the future. On the other hand increasing longevity does not necessarily translate into better health among older workers; people may simply live longer in a poor state of health (Chapman, LaPlante, and Wilenski 1986; Ycas 1987). Hence offsetring health patterns may not significantly affect furure retirement behavior.

In summary: our review of the future paths of the economic determinants of retirement suggests that the trend towards early retirement will slow and perhaps even reverse as the baby boom moves beyond middle age. This conclusion rests on anticipated patterns of financial incentives which have already been legislated (e.g. Social Security) and on others which we have good reason to expect to change (e.g. pensions). In addition, sectoral shifts in the economy away from blue collar work will also lead to reduced early retirement since productivity losses associated with older blue collar workers will be less important as this sector contracts. 


\section{Qther Labor Market Implications of an Aging Workforce}

Cerainly the most direct impact of an aging baby boom will be on retirement behavior. Nevertheless, the demographic change will certainly have other labor market consequences as well. Here we focus on two additional outcomes: unemployment, and wages for both older and younger workers.

While unemployment has been, and will remain, quite volatile over the business cycle, recent evidence indicates that the "natural rate" or what other economists have termed the "full employment-unemployment rate" has varied tremendously over time. For instance, the unemployment rate of $4.1 \%$ in 1956 was the lowest rate in the years immediately preceding and following it, indicating the top of the business cycle. The unemployment rate in two other peak years, 1979 and 1989 , were considerably higher at $5.8 \%$ and $5.0 \%$, respectively.

While different arguments have been advanced to explain changes in the natural unemployment rate over time, one important component of the explanation relies on the changing age structure of the workforce since the baby boom has come of age. In 1956, baby boomers were not yet in the labor force and had no effect on labor force statistics. However by 1979 , baby boomers had (for the most part) entered the labor market in full force, twisting the age distribution of the workforce towards younger workers. Younger workers generally have higher unemployment rates even during periods of full employment, because they experience relatively more frictional unemployment. As a result, the aggregate unemployment rate rose, since it is simply the weighted average of each age group's unemployment rate. The weight on younger, higher unemployment workers was therefore higher throughout the 1970's as a result of the numerousness of the baby boom cohort.

This aspect of rising unemployment patterns over time has been analyzed to some extent in the economics literature (Antos, et. al. 1979). For instance, as much as a third of the increase in national unemployment rates between 1957 and 1977 has been attributed to demographic change (Flaim 1979). This change is so massive that some analysts suggest that national unemployment 
rates "should be computed with a fixed age-distribution of weights" which will reduce the bias in time series observations of a changing age composition of the labor force (Cain 1979).

The good news is that the nation's unemployment rates should begin to fall, in mirror image to what happened during the 1970 's, as the baby boom ages. When baby boomers move into the older age group, the heavy weight on a demographic group which experiences relatively little unemployment will again reduce the aggregate unemployment rate. (Taking Cain's perspective, of course, the national unemployment rate will now be "too low", in contrast to the late 1970 's.)

As a group, older workers experience less unemployment then their younger counterparts. However those who do lose their job often experience a long spell of unemployment, and older workers may find this more costly than do younger ones because they experience a greater gap between earnings on the old and new job (Podgursky and Swaim 1987, Shapiro and Sandell 1987. Howland and Peterson 1988). Average unemployment duration may also be longer for the older individual than for younger workers. These findings have been interpreted as supportive of the view that firms are reluctant to hire older workers since they will have fewer years remaining on the job over which a firm can recoup investments in furm-specific training (Hutchens 1986, 1988).

We suggest that this pattern may change in the next thirty years as the baby boom ages. When boomers flooded the labor market during the 1970's and early 1980's, firms could readily hire younger workers and therefore spread training costs costs over many years. Wages offered to older workers during this time were quite low, if they could find work at all. In contrast, when the baby boom ages, companies may not be able to find enough younger workers. Though costs of hiring an older worker are still high, a shortage of young workers could increase the relative attractiveness of hiring an older worker. Therefore, looking toward 2020, we predict that displaced older workers will sull incur substantial losses upon unemployment, but on the positive side, losses observed during the 1970's and early 1980's may be greatly diminished.

We focus last on the likely effects of labor force aging on wages. One might suspect that baby boomers' relative wages will always be some what depressed because of crowding. In 
economic terms, a simple labor market model might predict that as the quantity of workers in a given age group increases, the wage they are paid will fall (this relies on the own price elasticity of demand being negative). However, this simple analysis ignores the possibilities of substitutes and complements across different labor market groups, and between labor and capital. More complete models which incorporate substitutes and complements have, to date, produced mixed evidence. For example, research on young baby boomers entering the labor market during the 1970's suggests support for the view that the large demographic bulge of workers forced down boomers' wages (Freeman 1979, Welch 1979, Russell 1982). However the reverse pattern does not seem to hold, at least in the one study which has addressed this question to date. Specifically, Levine and Mitchell (1988) found no evidence that wages of older workers would be substantially altered relative to younger workers as the baby boom ages, after estimating own- and cross-price demand elasticities for eight different demographic groups. It seems fair to say that no massive changes in wages can be attributed to demographic aging, on the basis of currently available evidence.

\section{Discussion and Conclusion}

This paper examines the likely effects of the aging of the baby boom on labor force astachment, unemployment, and wages. Labor market trends between now and 2020 are the focus of analysis, when the majority of the baby boom generation will confront its retirement decision.

We have demonstrated several inherent flaws in projection methods which make minor modifications to linear extrapolations. When behavioral patterns change, projections using the existing methodology are "too slow" to respond. Therefore we outline the key elements of a more comprehensive economic model to project the consequences of the demographic shock facing the labor market. On the basis of this analysis, we suggest the following conclusions:

1. The trend towards earlier retirement will slow and perhaps reverse in the next few decades. 
2. Unemployment should fall among older workers and the aggregate full-employment unemployment rate should also decline as the baby boom ages.

3. The aging of the baby boom will not depress wages substantially, either for older workers or for other demographic groups. 


\section{Beferences}

Aaron, H.J. (1982) Economic Effects of Social Security. Washington, D.C.: Brookings.

Aaron, H.J., B.P. Bosworth, and G. Burtless (1989), Can America Afford to Grow Old?: Paying for Social Security Washington, DC: The Brookings Institution.

Andrews, E. and O.S. Mitchell. (1986) "The Current and Future Role of Pensions in Old-Age Economic Security." Benefits Quarterly 2. pp. 25-36.

Antos, J., W. Mellow, and J. E. Triplett. (1979) "What is a Current Equivalent to Unemployment Rates of the Past?" Monthly Labor Review. March. pp. 36-46.

Bailey, M.N. (1987) "Aging and the Ability to Work". In Work.Health. and Income Among the Elderly. Ed. G. Burless. Washington, D.C.: Brookings.

Burkhauser, R. and J. Quinn. (1989) "American Patterns of Work and Retirement". In Redefining the Process of Retirement: An Intemational Perspective Ed. W. Schmahl. New York: Springer Verlag. pp. 91-113.

Burkhauser, R. and J. Quinn. (1983) "Is Mandatory Retirement Overrated?" Joumal ef Human Resources 18. pp. 337-358.

Burless, G. and A.H. Munnell (1991), "Does a Trend Toward Early Retirement Create Problems for the Economy?" In Retirement and Public Policy. Ed. A. H. Munnell. Washington, DC: National Academy of Social Insurance.

Burtless, G. and R. Moffitt. (1984) "The Effect of Social Security Benefits on the Labor Supply of the Aged". In Betirement and Economic Behavior. Eds. H. Aaron and G. Burtless. Washington, D.C.: Brookings. pp.135-171.

Cain, G. C. (1979) "The Unemployment Rate as an Economic Indicator." Menthly Labor Review. March. pp. 24-35.

Chapman, S. H., M.P. LaPlante, and G. Wilensky. (1986) "Life Expectancy and Health Status of the Aged." Social Security Bulletin. October. pp. 24-48.

Clark, R.L. and A. McDermed. (1990) The Choice of Pension Plan in a Changing Regulatory Environment. Washington, D.C.: American Enterprise Institute Press. 
Fields, G.S. and O.S. Mitchell (1984) Betirement. Pensions, and Social Security. Cambridge, Mass.: MTT Press.

Flaim, P. O. (1979) "The Effect of Demographic Changes on the Nation's Unemployment Rate." Monthly Labor Review. March. pp. 13-23.

Flaim, P. O. and H. N. Fullenion, Jr. (1978) "Labor Force Projections to 1990: Three Possible Paths." Monthly Labor Review December. pp. 25-35.

Freeman, R.B. (1979), "The Effect of Demographic Factors on Age-Earnings Profiles. "JoumaLef Human Resources 14. pp. 289-318.

Fullerton, H.N., Jr. (1988), "An Evaluation of Labor Force Projections to 1985." Monthly Labor Review 111. pp. 7-17. (1982), "How Accurate Were Projections of the 1980 Labor Force?" Monthly Labor Review 105. pp. : 15-21.

_(1985), "The 1995 Labor Force: BLS' Latest Projections." Monthly Labor Review 108. pp. $17-25$. (1987), "Labor Force Projections, 1986 to 2000." Monthly Labor Review 110. pp. 1929. (1989), "New Labor Force Projections, Spanning 1988 to 2000." Monthly Labor Review 112. pp. :3-12.

Fullerton, H.N., Jr. and J. Tschetter (1983), "The 1995 Labor Force: A Second Look." Monthly Labor Review 106. pp. 3-10.

Goldin, C. (1990) Understanding the Gender Gap. Oxford: Oxford University Press.

Gustman, A. and T. Steinmeier. (1991) "Changing the Social Security Rules for Work After 65". Industrial and Labor Relations Review. 44. pp.

Gustman, A. and T. Steinmeier. (1984) "Partial Retirement and the Analysis of Retirement Behavior". Industrial and Labor Relations Review 37 (April). pp. 403-415. Howland, M. and G.E. Peterson. (1988) "Labor Market Conditions and the Reemployment of Displaced Workers." Industrial and Labor Relations Review. October. pp. 109-122. 
Hutchens, R.M. (1986) "Delayed Payment Contracts and a Firm's Propensity to Hire Older Workers." Loumal of Labor Economics. October. pp. 439-457.

Hutchens, R.M. (1988) "Do Job Opportunities Decline with Age?" Industrial and Labor Relations Review. October. pp. 89-99.

Ippolito, R. (1986) Pensions. Economics, and Public Policy, Homewood, IL: Dow-Jones Irwin, Pension Research Council.

Ippolito, R. (1990) "Toward Explaining Earlier Retirement after 1970". Industrial and Laber Relations Review. 43 July. pp. 556-569.

Kutscher, R.E. (1987), "Overview and Implications of the Projections to 2000." Monthly Labor Review 110. pp. 3-9. (1989), "Projections Summary and Emerging Issues." Monthly Labor Review 112.pp. 66-74.

Lazear, E.P. (1988) "Adjusting to an Aging Labor Force." NBER Working Paper No. 2802. December.

Leonesio, M. (1990) "The Effects of the Social Security Eamings Test on the Labor Market Acrivity of Older Americans: A Review of the Evidence" Social Security Bulletin 53 May. pp. 2-21.

Levine, P.B. and O.S. Mitchell. (1988) "The Baby Boom's Legacy: Relative Wages in the Twenty-first Century", American Economic Review May. pp. 63-66.

Levy, F. (1987) Dollars and Dreams: The Changing American Income Distribution. New York: Russell Sage Foundation.

Lumsdaine, R., J.H. Stock, and D. Wise. (1990) "Efficient Windows and Labor Force Reduction". NBER Working Paper 3369. May.

Luzadis, R. and O.S. Mitchell. (forthcoming)"Explaining Pension Dynamics", Joumal of Human Besources.

McMillan, H.M. and J. B. Baesel. (1990) "The Macroeconomic Impact of the Baby Boom Generation," Journal of Macroeconomics. Spring. pp. 167-195. 
Mitchell, O.S. (1991) "The Effect of Mandatory Benefits Packages." In Research in Labor Economics. Eds. L. Bassi, D. Crawford, R. Ehrenberg. Greenwich, Ct: JAI Press, 1991. pp. 297-320.

Mitchell, O.S. (1991) "Pensions Reflect Employer and Employee Preferences." In Betirement and Public Policy. Ed. A. Munnell. Washington, D.C.: National Academy of Social Insurance, 1991.

Mitchell, O.S. (forthcoming [a])"Social Security Reforms and Poverty in Dual-Eamer Couples". Ioumal of Population Economics.

Mitchell, O.S. (forthcoming (b]) "Trends in Pension Formulas". In Trends in Pensions 1991. Eds. J. Turner and D. Beller.

Mitchell, O.S. and G.S. Fields (1985) "Rewards for Continued Work". In Horizontal Equity Uncertainty, and the Economics of Wellbeing. Eds. M. David and T. Smeeding. Chicago: University of Chicago Press.

Mitchell, O. S., P. B. Levine and S. Pozzebon. (1988) "Retirement Differences by Industry and Occupation." Joumal of Geroniology. August. pp. 545-551.

Mitchell, O.S. and R. Luzadis. (1988) "Changes in Pension Incentives Through Time." Induscrial and Labor Relations Review 42 (October). pp. 100-108.

Mitchell, O.S. with P. Levine and S. Pozzebon. (1988) "Retrement Differences by Occupation and Industry." The Geroniclegist 28 (August). pp. 545-51.

Moffitt, R. (1987) "Life-Cycle Labor Supply and Social Security: A Time Series Analysis". In Work. Health and Income Among the Elderly. Ed. G. Burtless. Washington, D.C.: Brookings.

Mutschler, P. (1986) "How Golden a Handshake?" Cempensation and Benefits Management Review 2 (Summer). pp. 277-283.

Piascentini, J. and T. Cerino. (1990) EBRI Databook on Emplovee Benefits. Washington, D.C: Employee Benefit Research Institute. 
Podgursky, M.and P.Swaim. (1987) "Job Displacement and Eamings Loss: Evidence from the Displaced Worker Survey." Industrial and Labor Relations Review. October. pp. 17-29. Poterba, J. and L. Summers (1987). "Public Policy Implications of Declining Old-Age Mortality". In Work, Health, and Income Among the Elderly. Ed. G. Burtless. Washington, D.C.: Brookings.

Quinn, J., R. Burkhauser, and D. Myers. (1990) Passing the Torch: The Influence of Economic Incentives on Work and Retirement. Kalamazoo, MI: Upjohn.

Ransom, R. and R. Sutch (1986) "The Labor of Older Americans: Retirement of Men on and off the Job". Ioumal of Economic History 46 (March). pp. 1-30.

Rejda, G. (1982) Economic and Social Security. New York: Wiley and Sons.

Russell, L. B.(1982) The Baby Boom Generation and the Economy. Washington, DC: Brookings Studies in Social Economics.

Sammartino, F. (1987). "The Effect of Health on Retirement". Social Security Bulletin 50 (February). pp. 31-47.

Shapiro, D. and S.H. Sandell. (1987) "The Reduced Pay of Older Job Losers: Age Discrimination and Other Explanations." In The Problem isn'tAge: Work and Older Americans. Ed. S. H. Sandell. New York: Praeger.

Tumer, J. and D. Beller, Eds. (1990) Trends in Pensions 1990. Pension and Welfare Benefit Agency, US Department of Labor, Government Printing Office.

U.S. Department of Commerce, Bureau of Economic Analysis. (1985) BEA Regional Projections.

U.S. Department of Health and Human Services, Social Security Administration. (1983) "Economic Projections for OASDI Cost Estimates, 1983: Actuarial Study No. 90."

U.S. Department of Labor, Bureau of Labor Statstics. (1991) Employment and Eamings. January.

Welch, F. (1979) "Effects of Cohort Size on Earnings: The Baby Boom's 'Financial Bust'." Joumal of Political Economy. October. pp. S65-97. 
Ycas, M.A. (1988) "Recent Trends in Health Near the Age of Retirement: New Findings from the Health Interview Survey." Social Security Bulletin. December. pp. 5-16. 
Table 1.

Labor Force Participation of Men Age 60 and over, $1870-1990$

\begin{tabular}{ccc} 
Year & & Percentage \\
\cline { 3 - 3 } 1870 & & 64.2 \\
1880 & & 64.3 \\
1900 & & 66.1 \\
1930 & & 64.5 \\
1937 & & 61.5 \\
1940 & & 54.7 \\
1950 & & 54.5 \\
1960 & & 45.4 \\
1970 & & 40.4 \\
1980 & 32.2 \\
1990 & 27.6
\end{tabular}

Source:

1870-1980: Ransom and Sutch (1988); note 1940 data not strictly comparable. 1990: USDOL (1991). 
Table 2a.

Current and Projected Labor Force Participation Rates by Sex and Age

\begin{tabular}{|c|c|c|c|c|c|}
\hline & $\begin{array}{c}\text { (1) } \\
\text { Observed } \\
1990\end{array}$ & $\begin{array}{r}(2) \\
\text { BLS } \\
2000 \\
\end{array}$ & $\begin{array}{r}(3) \\
\text { SSA } \\
2000 \\
\end{array}$ & $\begin{array}{r}(4) \\
\mathrm{BEA} \\
2015 \\
\end{array}$ & $\begin{array}{r}(5) \\
\text { SSA } \\
2020 \\
\end{array}$ \\
\hline All Men & 76.1 & 75.9 & 77.5 & 72.0 & 72.0 \\
\hline $\begin{array}{l}\text { Age group: } \\
16-24\end{array}$ & 71.5 & & & 74.8 & \\
\hline $\begin{array}{l}16-19 \\
20-24\end{array}$ & $\begin{array}{l}55.7 \\
84.3\end{array}$ & $\begin{array}{l}59.0 \\
86.5\end{array}$ & $\begin{array}{l}66.9 \\
86.9\end{array}$ & $\begin{array}{l}63.9 \\
84.0\end{array}$ & $\begin{array}{l}67.7 \\
87.4\end{array}$ \\
\hline $25-54$ & 93.4 & & & 92.4 & \\
\hline $\begin{array}{l}25-34 \\
25-29 \\
30-34\end{array}$ & $\begin{array}{l}94.2 \\
93.8 \\
94.6\end{array}$ & 94.1 & $\begin{array}{l}95.0 \\
95.2\end{array}$ & 92.5 & $\begin{array}{l}95.3 \\
95.4\end{array}$ \\
\hline $\begin{array}{l}35-44 \\
35-39 \\
40-44\end{array}$ & $\begin{array}{l}94.4 \\
94.9 \\
93.9\end{array}$ & 94.3 & $\begin{array}{l}95.1 \\
94.1\end{array}$ & 94.9 & $\begin{array}{l}95.4 \\
94.4\end{array}$ \\
\hline $\begin{array}{r}45-54 \\
45-49 \\
50-54\end{array}$ & $\begin{array}{l}90.7 \\
92.3 \\
88.8\end{array}$ & 90.5 & $\begin{array}{l}92.0 \\
87.7\end{array}$ & 90.2 & $\begin{array}{l}92.0 \\
86.4\end{array}$ \\
\hline $\begin{array}{l}55-64 \\
55-59 \\
60-64\end{array}$ & $\begin{array}{l}67.7 \\
79.8 \\
55.5\end{array}$ & 68.1 & $\begin{array}{l}79.5 \\
62.1\end{array}$ & 62.9 & $\begin{array}{l}75.3 \\
57.3\end{array}$ \\
\hline $\begin{array}{c}65+ \\
65-69 \\
70+\end{array}$ & $\begin{array}{l}16.4 \\
26.0 \\
10.8\end{array}$ & 14.7 & $\begin{array}{l}27.0 \\
10.6\end{array}$ & 13.0 & $\begin{array}{l}26.3 \\
10.7\end{array}$ \\
\hline
\end{tabular}


Table 2b.

Current and Projected Labor Force Participation Rates by Sex and Age (continued)

\begin{tabular}{|c|c|c|c|c|c|}
\hline & $\begin{array}{c}(1) \\
\text { Observed } \\
1990\end{array}$ & $\begin{array}{c}(2) \\
\text { BLS } \\
2000 \\
\end{array}$ & $\begin{array}{r}(3) \\
\text { SSA } \\
2000 \\
\end{array}$ & $\begin{array}{c}(4) \\
\text { BEA } \\
2015 \\
\end{array}$ & $\begin{array}{r}(5) \\
\text { SSA } \\
2020 \\
\end{array}$ \\
\hline All Women & 57.5 & 62.6 & 59.0 & 57.5 & 54.6 \\
\hline $\begin{array}{l}\text { Age group: } \\
16-24\end{array}$ & 63.1 & & & & \\
\hline $\begin{array}{l}16-19 \\
20-24\end{array}$ & $\begin{array}{l}51.8 \\
71.6\end{array}$ & $\begin{array}{l}59.6 \\
77.9\end{array}$ & $\begin{array}{l}62.4 \\
76.9\end{array}$ & $\begin{array}{l}59.1 \\
84.5\end{array}$ & $\begin{array}{r}63.4 \\
6.7\end{array}$ \\
\hline $25-54$ & 74.1 & & & 79.9 & \\
\hline $\begin{array}{l}25-34 \\
25-29 \\
30-34\end{array}$ & $\begin{array}{l}73.6 \\
73.8 \\
73.4\end{array}$ & 82.4 & $\begin{array}{l}75.1 \\
74.4\end{array}$ & 84.3 & $\begin{array}{l}75.8 \\
75.4\end{array}$ \\
\hline $\begin{array}{l}35-44 \\
35-39 \\
40-44\end{array}$ & $\begin{array}{l}76.5 \\
75.5 \\
77.6\end{array}$ & 84.9 & $\begin{array}{l}76.3 \\
78.0\end{array}$ & 85.6 & $\begin{array}{l}77.0 \\
78.4\end{array}$ \\
\hline $\begin{array}{c}45-54 \\
45-49 \\
50-54\end{array}$ & $\begin{array}{l}71.2 \\
74.8 \\
66.9\end{array}$ & 76.5 & $\begin{array}{l}76.4 \\
71.6\end{array}$ & 70.7 & $\begin{array}{l}76.3 \\
71.7\end{array}$ \\
\hline $\begin{array}{l}55-64 \\
55-59 \\
60-64\end{array}$ & $\begin{array}{l}45.3 \\
55.3 \\
35.5\end{array}$ & 49.0 & $\begin{array}{l}56.5 \\
38.8\end{array}$ & 43.0 & $\begin{array}{l}55.0 \\
36.7\end{array}$ \\
\hline $\begin{array}{c}65+ \\
65-69 \\
70+\end{array}$ & $\begin{array}{r}8.7 \\
17.0 \\
4.8\end{array}$ & 7.6 & $\begin{array}{r}17.6 \\
5.4\end{array}$ & 7.3 & $\begin{array}{r}18.0 \\
5.5\end{array}$ \\
\hline
\end{tabular}

Source:

Column 1: USDOL (1991).

Column 2: Fullerton (1989).

Column 3 and 5: Social Security Administration (1983).

Column 4: Bureau of Economic Analysis (1985). 
Table 3.

Comparison of Actual and "Short Term"

Labor Force Participation Rate Projections by Sex and Age

\section{All Men}

\section{Age group:}

16-19

20-24

$25-54$

$25-34$

$35-44$

$45-54$

$55-64$

$55-59$

60.64

$65+$

$65-69$

$70+$

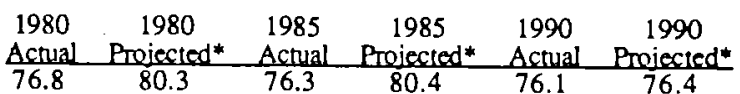

$\begin{array}{llllll}61.2 & 56.7 & 56.8 & 54.3 & 55.7 & 64.8\end{array}$

$\begin{array}{llllll}85.7 & 87.2 & 85.0 & 82.3 & 84.3 & 85.0\end{array}$

94.2

94.6

96.2

94.7

$93.4 \quad 93.1$

$95.0 \quad 97.4$

$\begin{array}{lll}95.0 & 91.0 & 95.3\end{array}$

71.4

83.7

79.6

55.6

88.2

$67.7 \quad 65.0$

$18.3 \quad 21.8$

$\begin{array}{ll}24.4 & 35.9 \\ 10.5 & 13.2\end{array}$

$16.4 \quad 15.0$

\begin{tabular}{|c|c|c|c|c|c|c|}
\hline All Women & 50.9 & 41.9 & 54.5 & 43.7 & 57.5 & 57.1 \\
\hline $\begin{array}{l}\text { Age group: } \\
16-19 \\
20-24\end{array}$ & $\begin{array}{l}53.0 \\
69.0\end{array}$ & $\begin{array}{l}46.6 \\
52.6\end{array}$ & $\begin{array}{l}41.2 \\
71.8\end{array}$ & $\begin{array}{l}52.1 \\
57.9\end{array}$ & $\begin{array}{l}51.8 \\
71.6\end{array}$ & $\begin{array}{l}62.8 \\
80.4\end{array}$ \\
\hline $\begin{array}{l}25-54 \\
25-34 \\
35-44 \\
45-54\end{array}$ & $\begin{array}{l}65.3 \\
65.2 \\
59.6\end{array}$ & $\begin{array}{l}40.3 \\
50.0 \\
59.5\end{array}$ & $\begin{array}{l}70.9 \\
71.8 \\
64.4\end{array}$ & $\begin{array}{l}46.7 \\
53.6 \\
55.6\end{array}$ & 74.1 & 72.4 \\
\hline $\begin{array}{r}55-64 \\
55-59 \\
60-64\end{array}$ & 41.1 & 47.3 & $\begin{array}{l}50.3 \\
33.4\end{array}$ & $\begin{array}{l}52.3 \\
38.7\end{array}$ & 45.3 & 39.8 \\
\hline $\begin{array}{c}65+ \\
65-69 \\
70+\end{array}$ & 7.6 & 9.9 & $\begin{array}{r}13.5 \\
4.3\end{array}$ & $\begin{array}{r}16.3 \\
5.1\end{array}$ & 8.7 & 6.2 \\
\hline
\end{tabular}

Notes:

*All projections assume moderate economic growth. Projections for 1980 were made in 1965 , 1985 projections in 1970 and 1990 projections in 1978.

\section{Source:}

Columns 1 and 2: Fullerton (1982).

Columns 3 and 4: Fullerton (1988).

Column 5: Flaim and Fullerton (1978).

Column 6: USDOL (1991). 
Table 4.

A Comparison of Projection Errors Using Linear Extrapolations and BLS Results, Selected Demographic Groups and Years

$\begin{array}{llll}1980 & 1985 & 1990 & 2000\end{array}$

\section{Labor Force Participacion Rates of:}

Women Age 20-24

Observed

BLS Projection

Linear Extrapolation

Men Age 55.64

Observed

BLS Projection

Linear Extrapolation

Women Age 55-64

Observed

BLS Projection

Linear Extrapolation

\section{0}

52.6

52.1

71.8

57.9

65.2

71.6

80.4

81.6

77.9

88.5

$\begin{array}{llll}71.4 & 67.9 & 67.7 & \ldots \\ 83.7 & 81.3 & 65.0 & 68.1 \\ 83.6 & 77.9 & 62.7 & 53.5\end{array}$

$\begin{array}{llll}41.1 & 42.0 & 45.3 & -.- \\ 47.3 & 45.5 & 39.8 & 49.0 \\ 56.6 & 56.6 & 43.8 & 41.1\end{array}$




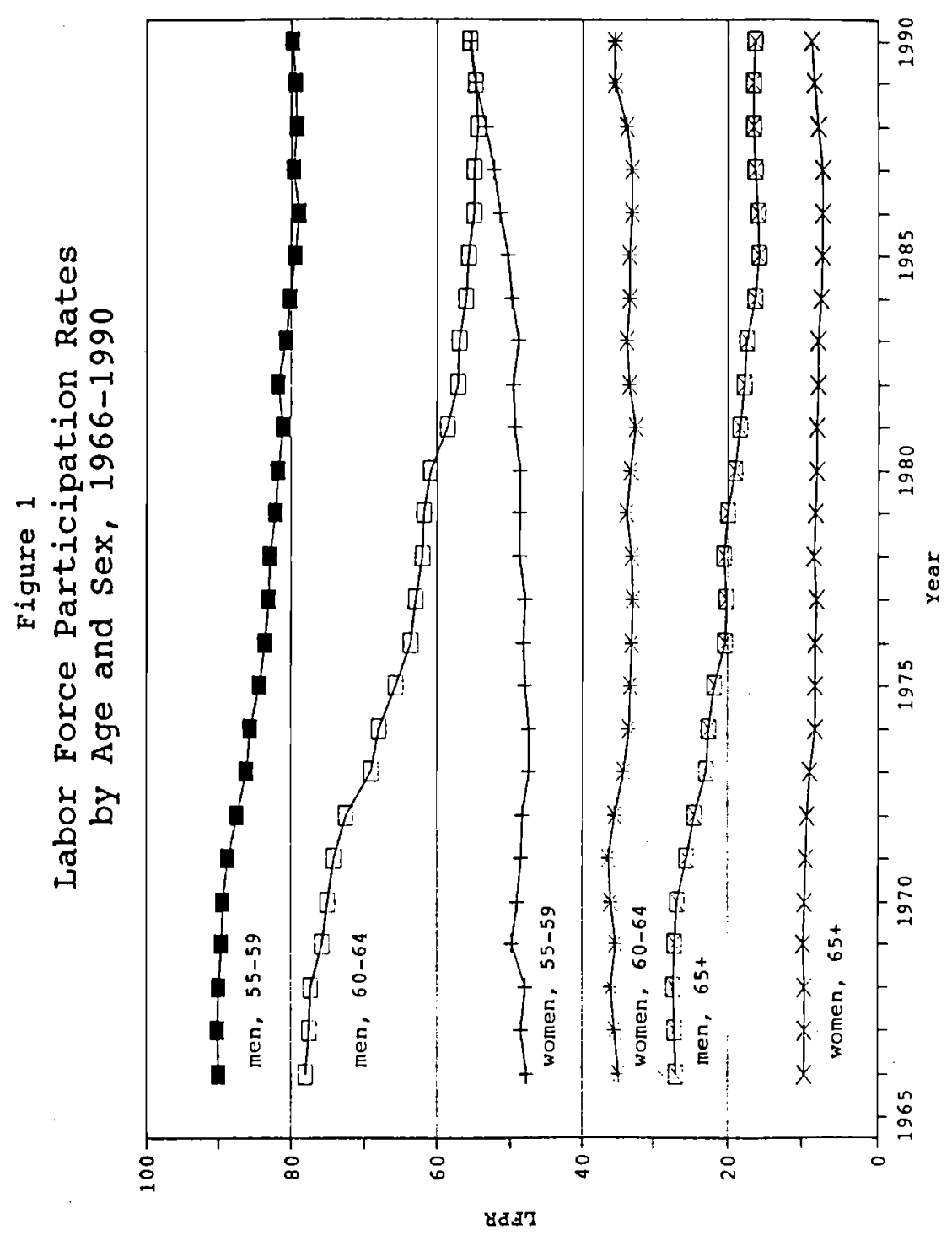




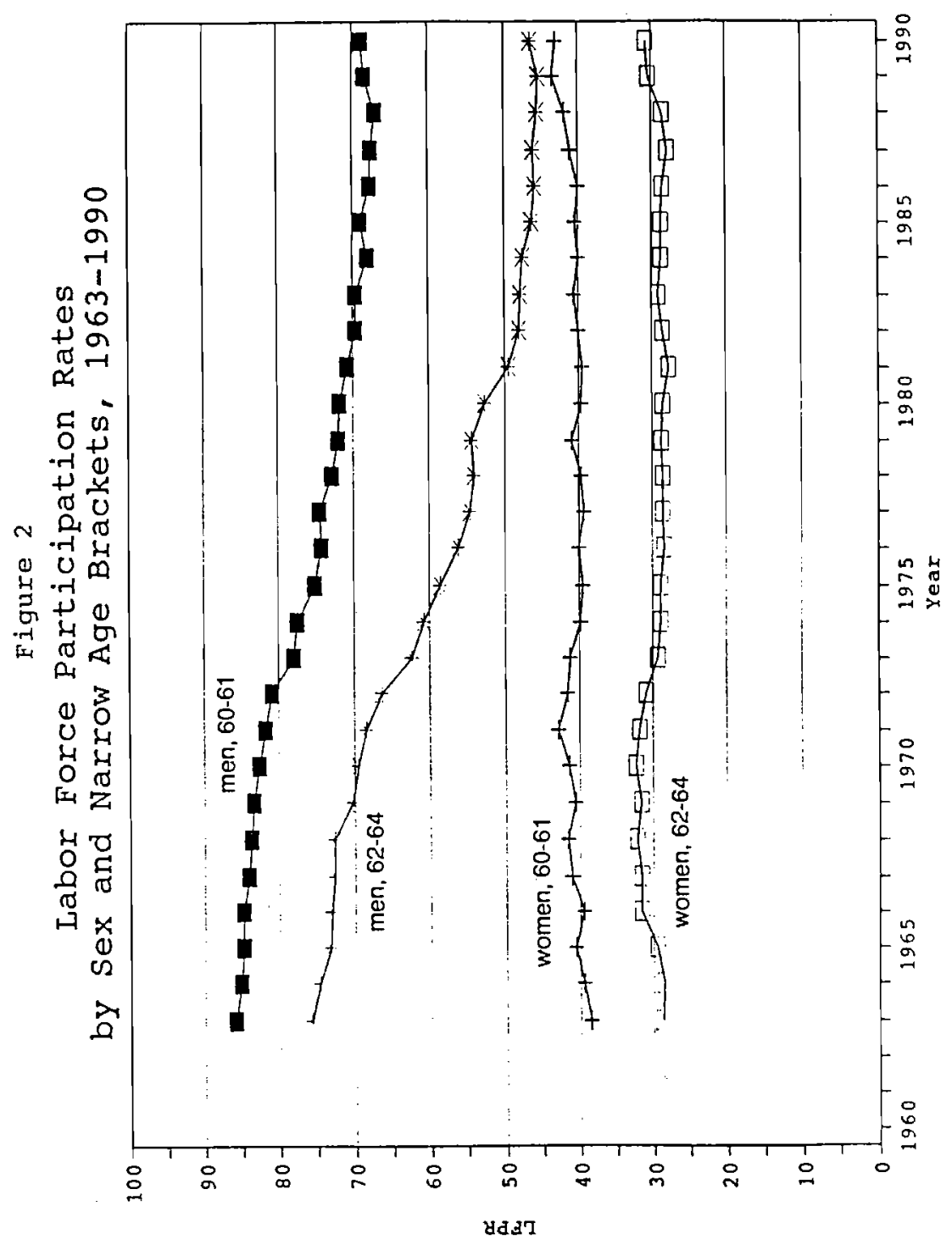




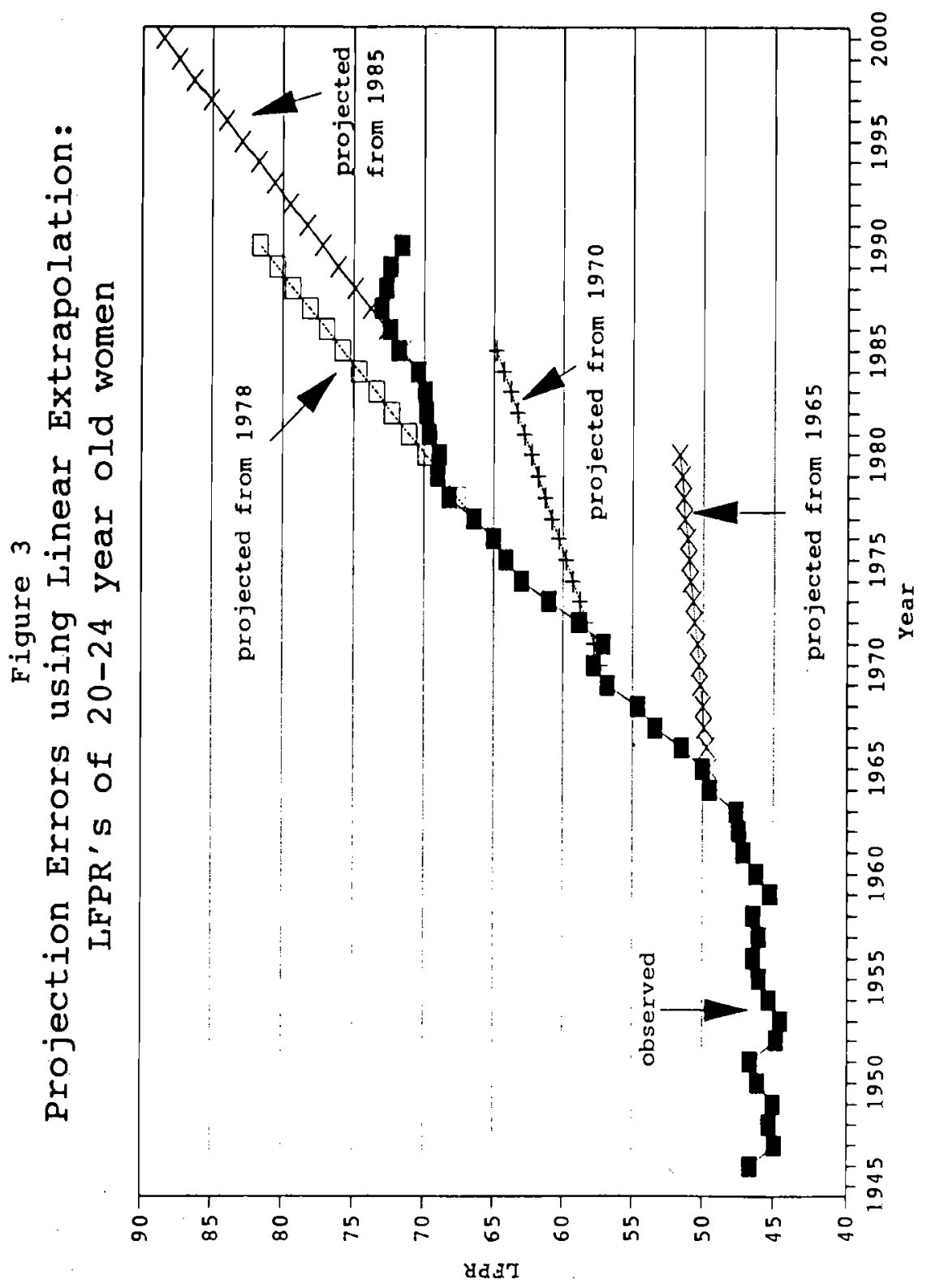




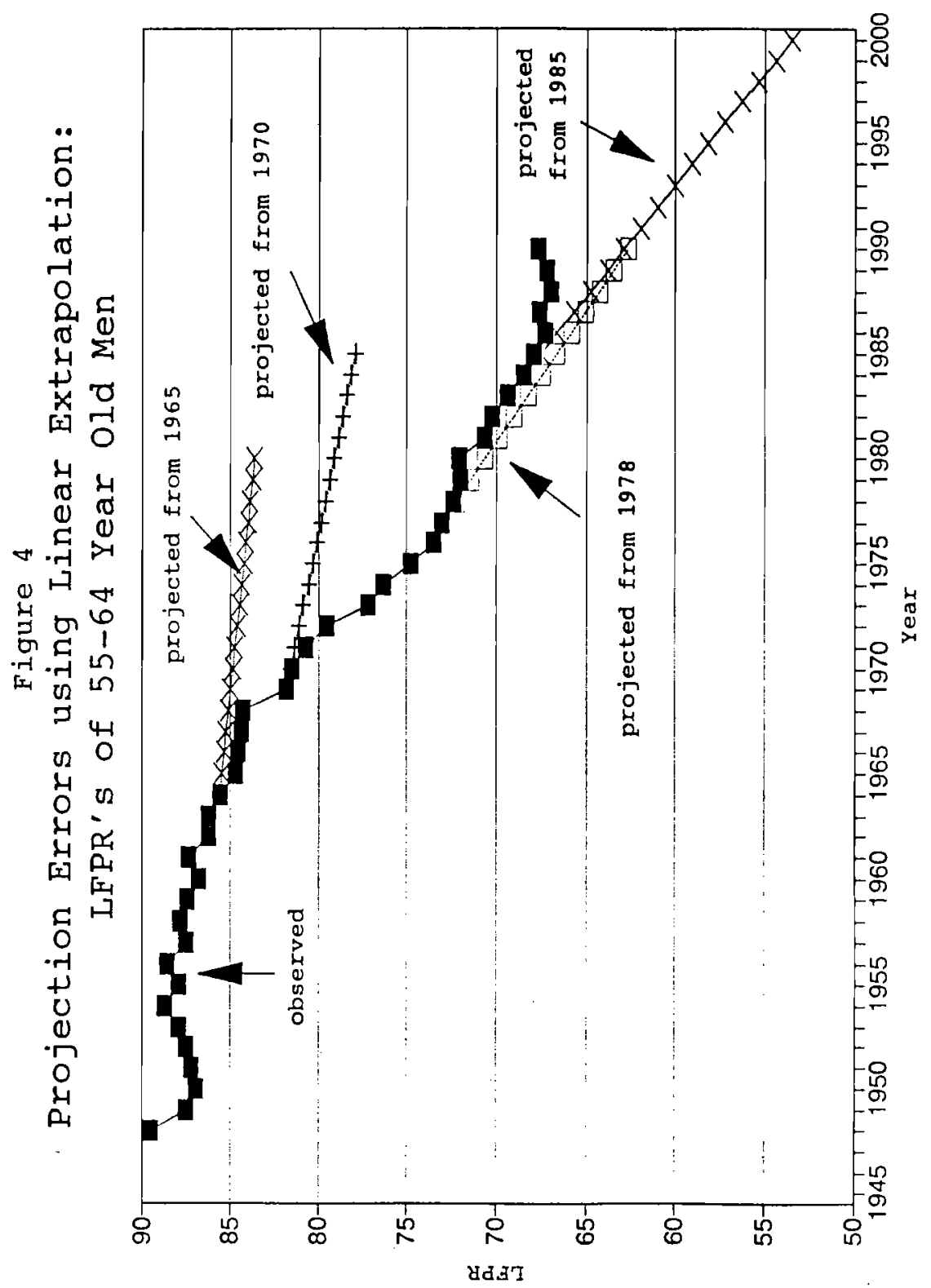




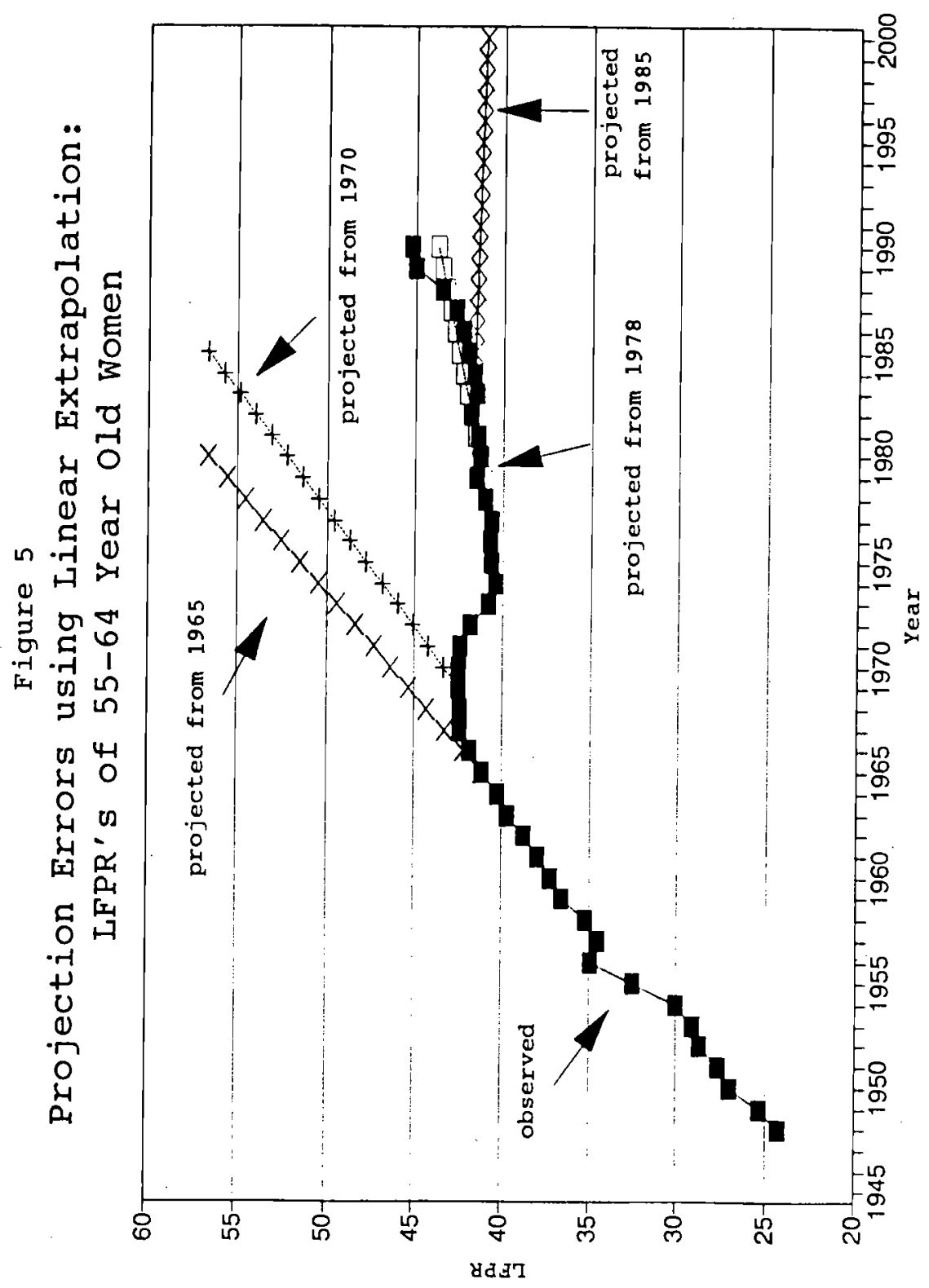

